\title{
The Political Text of Racialized Bodies
}

\author{
GURJIT SANDHU \\ Queen's University \\ Co-Editor, Journal of Critical Race Inquiry
}

\section{Editor's Introduction}

Welcome to the second volume of the Journal of Critical Race Inquiry. The first paper by Michelle Montgomery is "Identity Politics: The Mixed-race American Indian Experience." I have authored the second paper, "Creating Inclusive Classrooms Using Postcolonial and Culturally Relevant Literacy.” The third paper is by Suzanne Narain, “The Re-branding Project: The Genealogy of Creating a Neoliberal Jane and Finch.” Montgomery examines racial selfidentification amongst mixed-race American Indian college student. Through an inquiry into students' perception of self, how they want to be perceived, and economic and historical influences, Montgomery explores racial identity choices. By unpacking the blood quantum debate, Montgomery advances our understanding of the deliberate design of racial boundaries. In my paper, I take a closer look at how the identities of South Asian Canadian adolescent girls are informed by the literacies and texts to which they have access. Introducing culturally relevant curricula and culturally response teaching to these students was salient to their engagement with 
the materials and exploration of identities. Narain's work examines the stigmas associated with the Jane and Finch neighbourhood in Toronto. By taking the reader through a genealogy of the re-branding of Jane and Finch into "University Heights", Narain highlights the social injustices and exclusions experienced by the very people at the heart of this community. In all three papers, the authors are attentive to stories - the stories we tell ourselves are equally as important as the stories that are told about us. By interrupting the texts that name racialized bodies and the spaces they occupy, we disrupt the power and politics of a racial ideology.

Being a part of the development of the Journal of Critical Race Inquiry from the time it was an idea in 2008 to our second volume in 2012 has been a rewarding journey. The enthusiastic responses to CRI from readers, authors, reviewers, editorial staff and many more is a true testament to the value and need for ongoing critical race work. As I move on from my service as CRI co-editor, I'd like to extend a heartfelt welcome to Dr. Scott Morgensen as CRI co-editor. Dr. Morgensen works at the intersections of queer, feminist, Indigenous, critical race, and settler-colonial studies. Together with Dr. Walker, they have exciting new initiatives planned that will continue to build on the strength of CRI. I look forward to reading the next issue. 